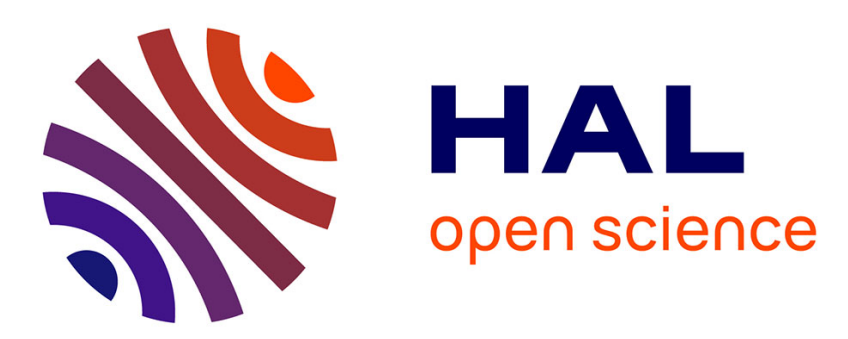

\title{
The Aculeata of French Polynesia. III. Sphecidae, with the record of three new species for the Society Islands (Hymenoptera)
}

\author{
Thibault Ramage, Sylvain Charlat, Frédéric Jacq
}

\section{- To cite this version:}

Thibault Ramage, Sylvain Charlat, Frédéric Jacq. The Aculeata of French Polynesia. III. Sphecidae, with the record of three new species for the Society Islands (Hymenoptera). Bulletin de la Société Entomologique de France, 2015, 120 (2), pp.157-163. hal-02140484

\author{
HAL Id: hal-02140484 \\ https://hal.science/hal-02140484
}

Submitted on 27 May 2019

HAL is a multi-disciplinary open access archive for the deposit and dissemination of scientific research documents, whether they are published or not. The documents may come from teaching and research institutions in France or abroad, or from public or private research centers.
L'archive ouverte pluridisciplinaire HAL, est destinée au dépôt et à la diffusion de documents scientifiques de niveau recherche, publiés ou non, émanant des établissements d'enseignement et de recherche français ou étrangers, des laboratoires publics ou privés. 


\title{
The Aculeata of French Polynesia. III. Sphecidae, with the record of three new species for the Society Islands (Hymenoptera)
}

\author{
by Thibault RAMAGE ${ }^{1}$, Sylvain CHARLAT ${ }^{2}$ \& Frédéric $\mathrm{JACQ}^{3}$ \\ ${ }^{1} 9$ quartier de la Glacière, F - 29900 Concarneau <thibault.ramage@hotmail.fr> \\ ${ }^{2}$ CNRS (UMR 5558), Université Lyon 1, Laboratoire Biométrie \& Biologie Évolutive, bât. Mendel, \\ 43 boulevard du 11-novembre-1918,F-69622 Villeurbanne<sylvain.charlat@univ-lyon1.fr> \\ ${ }^{3}$ B. P. 141260, Polynésie française (Tahiti), F-98701 Arue <jacq_fred@hotmail.com>
}

\begin{abstract}
The sphecid fauna of French Polynesia, limited until now to Sceliphron caementarium (Drury), is increased by three species recently introduced in the Society Islands: Sceliphron laetum (Smith), S. curvatum (Smith) and Chalybion bengalense (Dahlbom). The presence of $S$. curvatum in French Polynesia considerably broadens the known distribution of this species which is native to Asia and introduced into Europe and both North and South America. Chalybion bengalense is also reported from New Caledonia for the first time, as well as Sceliphron laetum from Wallis and Futuna. The distribution, biology and potential impact of each species on the arachnofauna are discussed. An identification key to the Sphecidae of French Polynesia is provided.

Résumé. - Les Aculéates de Polynésie française. III. Les Sphecidae, avec le premier signalement de trois espèces pour les îles de la Société (Hymenoptera). La faune des Sphecidae de Polynésie française, limitée jusqu'à présent à Sceliphron caementarium (Drury), est ici augmentée de trois espèces récemment introduites dans les îles de la Société : Sceliphron laetum (Smith), S. curvatum (Smith) et Chalybion bengalense (Dahlbom). La présence de S. curvatum en Polynésie française agrandit considérablement la répartition connue de cette espèce originaire d'Asie et introduite en Europe comme aux Amériques. Chalybion bengalense est également cité de NouvelleCalédonie pour la première fois, de même que Sceliphron laetum de Wallis-et-Futuna. La distribution, la biologie, ainsi que l'impact potentiel de chaque espèce sur l'arachnofaune sont précisés. Une clé d'identification est proposée, permettant de distinguer l'ensemble des espèces présentes sur le territoire.
\end{abstract}

Keywords. - Sceliphron, Chalybion, identification key, French Polynesia, New Caledonia, Wallis and Futuna.

The sphecid fauna of French Polynesia has been sporadically reviewed for more than a century (CAmeron, 1886; Williams, 1932; Pulawski, 2013b) and here we add to the known fauna (Sceliphron caementarium) three introduced species that we recently collected. These new wasps, due to their habits of building nests on man-made structures, must have been introduced through international trade, like other recently recorded Aculeata species (RAMAGE et al., 2015b). One of these three species, Sceliphron curvatum (Smith, 1870), seems to be restricted to urban areas for now.

Sceliphron laetum (Smith, 1856) was collected on Moorea, Huahine, Raiatea and Taha'a (Society Islands), S. curvatum on Tahiti and Bora Bora (Society Islands) and Chalybion bengalense (Dahlbom, 1845) on Moorea and Huahine. The latter is also reported for the first time from New Caledonia and S. laetum from Wallis and Futuna.

These sphecid wasps are all spiders predators and may have an impact on the arachnofauna of French Polynesia. The biology and potential impact of each species are discussed below.

Abbreviations. - CS, Symbiocode collection, Lyon (Sylvain Charlat); CTR, Thibault Ramage's personal collection; MNHN, Muséum national d'Histoire naturelle, Paris.

Chresonymy. - Under each taxa, the original combination and the synonymies and combinations used in the bibliography relative to French Polynesia are listed. 
Family Sphecidae Latreille, 1802

Subfamily Sceliphrinae Ashmead, 1899

Tribe Sceliphrini Ashmead, 1899

Genus Sceliphron Klug, 1801

Sceliphron caementarium (Drury, 1773)

Sphex caementarius Drury, 1773: 105.

Pelopoeus tahitensis Saussure, 1867: 27.

Sceliphron tahitensis (Saussure, 1867).

Sphex economicus Curtiss, 1938: 154.

Material examined. - French Polynesia: 1 , Tahiti (MNHN); 1 , Raiatea, Muséum Paris, coll. R. du Buysson 1900 (MNHN); 3 ㅇ, Tahiti, Muséum Paris, coll. J. de Gaulle 1919 (MNHN); 1 ô, Tahiti: Punaauia, 1-7.VII.1959, J. Rageau, Muséum Paris, collection ORSTOM (MNHN); 1 + , Tahiti: Papeete, (Patutoa), VI.1959, J. Rageau, Muséum Paris, collection ORSTOM (MNHN); 1 +, Moorea, Pihaena, 2.VI.2007, S. Charlat (CS); 6 + , Nuku Hiva, Muséum Paris, îles Marquises, P. Siméon Delmas, 1924 (MNHN); 2 9, îles Marquises, Taiohaé, P. Siméon Delmas, 1928 (MNHN); 2 Oे, I. Rurutu, 11.X.1962, (MNHN); 1 \&, Makatea, Vaitepaua, 19.IV.2007, F. Jacq (CTR); 1 †, Fakahina, Hokikakika, 17.II.2011, F. Jacq (CTR); 1 ㅇ, archipel des Gambier, île Mangaréva, Rikitea, G. Seurat, 1905 (MNHN). New Caledonia: 1 ô, Nouméa, Nelle Calédonie, 15.II.1948 (MNHN). Wallis and Futuna: 1 + , I. F. O. Wallis Mata-utu, J. Rageau, 20.X.1958 (MNHN); 1 +, idem, 12.XI.58 (MNHN); 1 §, idem, 20.X.1958 (MNHN).

Diagnosis. - Tall species (about $2.5 \mathrm{~cm}$ ), black and yellow with infuscated wings. Although its color pattern is variable throughout its wide distribution (VAN DER VeChT \& VAN BReugel, 1968), the French Polynesian populations have the same color pattern, with complete yellow markings on the mesosoma, propodeum declivity more or less yellow, black petiole and a yellow posterior band on the first gastric tergite. Sceliphron caementarium can be separated from $S$. laetum by the color of the petiole (black for S. caementarium, yellow for S. laetum) (HARRIs, 1992) and from $S$. curvatum by the shape of the petiole (straight for $S$. caementarium, curved for S. curvatum).

Distribution. - North America (native range); Central America, Antilles, Peru, Europe, Madeira, Canary Islands, Iran, China, Japan, Australia, Fiji, Micronesia, New Zealand, New Caledonia, Wallis and Futuna Islands, Hawaiian Islands, Samoa, Cook Islands, French Polynesia (introduced).

Biology. - In its native range, Sceliphron caementarium is known to prey mostly upon spiders of the families Araneidae (Acanthepeira Marx, 1883, Araneus Clerck, 1757, Araniella Chamberlin \& Ivie, 1942, Argiope Audouin, 1826, Eustala Simon, 1895, Neoscona Simon, 1864), Salticidae (Platycryptus Hill, 1979, Phidippus Koch, 1846) and Thomisidae (Misumena Latreille, 1804, Misumenoides Cambridge, 1900, Misumenops Cambridge, 1900, Xysticus Koch, 1835) with a few prey in the Tetragnathidae (Meta Koch, 1836), Oxyopidae (Oxyopes Latreille, 1804) and Lycosidae (Schizocosa Chamberlin, 1904) (RAU, 1935).

In French Polynesia, the preys of $S$. caementarium have been documented to be Frigga crocuta (Taczanowski, 1878), Plexippus paykulli (Audouin, 1826) (Salticidae) and Neoscona theisi (Walckenaer, 1842) (Araneidae) (BERLAND, 1945). In its native range in the USA, Araneidae are the most frequent preys, whereas in French Polynesia Salticidae were preyed upon more numerousously than Araneidae (RAU, 1935).

The nests of Sceliphron caementarium are mostly composed of two to six cells, each containing an average of nine spiders (RAU \& RAU, 1916).

Sceliphron laetum (Smith, 1856)

Pelopaeus laetus Smith, 1856: 229.

Material examined. - French Polynesia: 1 ㅇ, Moorea, Vaiare, 18.IV.2007, S. Charlat (CS); 1 †, Huahine, vallée de Parea, 3.VII.2007, S. Charlat (CS); 2 ㅇ, Taha’a, vallée de Vaipihae, 30 m, 
16³'20.29”S - 151`31'47.16”W, 29.IX.2012, Th. Ramage (CTR); 1 ㅇ, Taha'a, vallée de Patio,

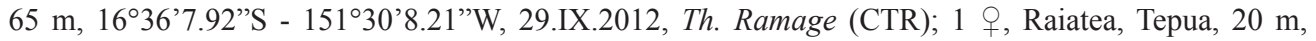

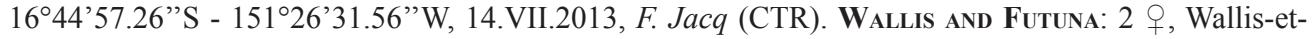
Futuna, III.1994, Parage rec. (MNHN).

Diagnosis. - Tall species (about $3 \mathrm{~cm}$ ), black and yellow with somewhat yellow wings. Sceliphron laetum can be easily confused with $S$. caementarium, but in French Polynesia S. laetum has a yellow petiole, whereas $S$. caementarium has a black petiole. S. laetum can be distinguished from $S$. curvatum by having a straight rather than curved petiole (fig. 1).

Distribution. - Australia, Papua New Guinea, Indonesia (native range); Guam, Vanuatu, New Zealand, Wallis and Futuna, French Polynesia (introduced).

Biology. - In Papua New Guinea, Sceliphron laetum preys almost exclusively upon spiders of the family Araneidae (genera Argiope, Cyclosa, Cyrtarachne, Gasteracantha, Neoscona, Poltys, Cyrtophora and Phonognatha) but one species each of Salticidae, Oxyopidae and Thomisidae have also been found in nests (ElGAR \& JEBB, 1999). The nest cells of S. laetum contain an average of five spiders (Elgar \& JEBB, 1999).

Comments. - S. laetum is new to the entomofauna of Wallis and Futuna and French Polynesia and seems to be currently restricted to the Society Islands. S. laetum has probably been introduced to French Polynesia and Wallis and Futuna through international trade from other Pacific islands.

No nests of $S$. laetum have yet been studied from French Polynesia but the preyed spiders are probably of the families Araneidae and Salticidae, similar to $S$. caementarium. Seven species of Araneidae (s. str.) and 23 species of Salticidae are known from French Polynesia (DiERKENS \& Charlat, 2011; Platnick, 2014).

\section{Sceliphron curvatum (Smith, 1870)}

Pelopaeus curvatus Smith, 1870: 187.

Material examined. - French Polynesia: 1 + , Tahiti, Pirae, 25 m, 17³2'2.86’'S - 149³2’34.46”'W, 27.XII.2007, F. Jacq (CTR); 1 q, Tahiti, Arue, 200 m, 17³2'8.26”'S - 149³1'6.74”'W, V.2012, F. Jacq

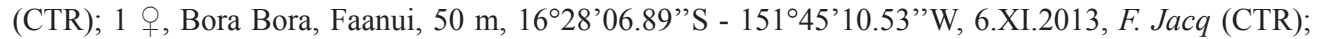
1 q, Tahiti, Papeete, Sainte-Amélie, 60 m, 17³3'01.80”'S - 149³3'55.97'”, 19.I.2014, F. Jacq (CTR); 1 q, idem, 2.III.2014, F. Jacq (CTR); 1 ô, idem, 19.III.2014, F. Jacq (CTR); 1 ठ, idem, 23.III.2014, F. Jacq (CTR); 1 ㅇ, Tahiti, Punaauia, Vaiopu, 200 m, 17³7'46.5”S - 149³5'44.6”W, IV.2014, C. Peyterman (CTR).

Diagnosis. - Medium-sized species (1.5-2 cm), smaller than the two other Sceliphron species from French Polynesia. Black and yellow, legs reddish except the coxae and first half of femora being black, wings yellowish (fig. 3). Sceliphron curvatum can be confused with the two other Sceliphron species from French Polynesia but can be distinguished by its curved rather than straight petiole (HENSEN, 1987) (fig. 2).

Distribution. - Iraq, Afghanistan, Tajikistan, Pakistan, Uzbekistan, Kyrgyzstan, Kazakhstan, India, Nepal (native range); Europe, South America, North America, French Polynesia (introduced).

Biology. - In Europe, Sceliphron curvatum is known to prey mostly upon spiders in the families Araneidae and Salticidae. Some Thomisidae, Philodromidae, Theridiidae, Sparassidae, Anyphaenidae and Oxyopidae are also preyed upon (RAHOLA, 2005). A cricket, Arachnocephalus vestitus Costa, 1855 (Orthoptera, Mogoplistidae), in the south of France, is the only Orthopteran recorded to be preyed upon by a Sceliphron (RAHOLA, 2007).

Five to 20 spiders are placed in each $S$. curvatum nest cell, with a mean of 13 spiders: 7 spiders per cell for future males, 16 spiders per cell for future females (RAHOLA, 2005). 

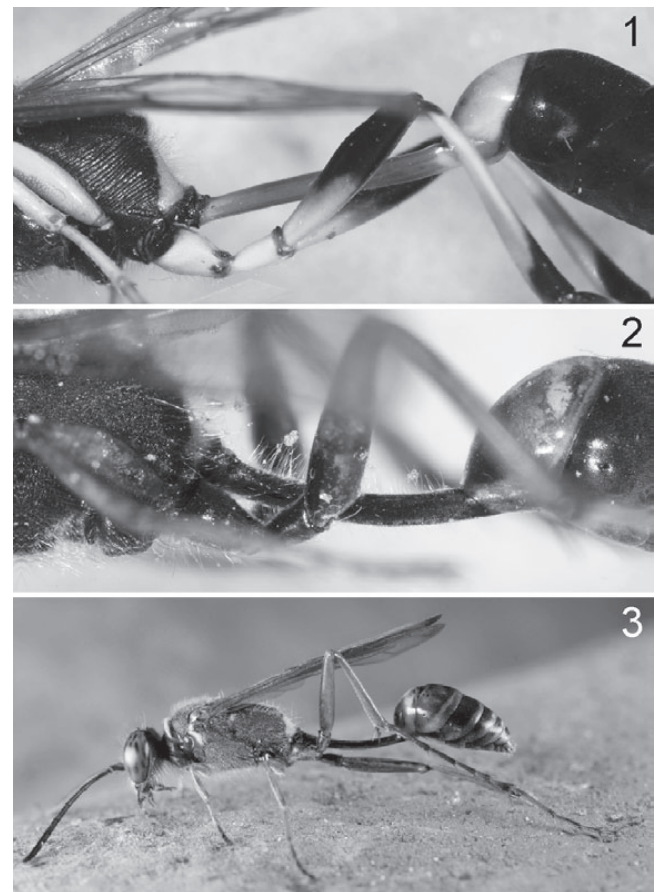

Fig. 1-3. - Sceliphron spp. - 1, Sceliphron laetum (Smith), petiole, side view. - 2, Sceliphron curvatum (Smith), petiole, side view. - 3, Sceliphron curvatum (đ)), side view. (Photos 1-2, Th. Ramage; photo 3, F. Jacq).

Comments. - Sceliphron curvatum has been recorded in Europe since 1979 and in France since 1998 (BITSCH \& BARBIER, 2006; ĆETKOvić et al., 2011). Recently it has also been recorded from the South American countries of Chile and Argentina (Pulawski, 2013b) and the North American countries of Canada and the USA (EATON, 2014). S. curvatum is a new record for French Polynesia and the Pacific.

The origin of the population of Sceliphron curvatum introduced to French Polynesia is probably from Europe, most likely from France, through international trade. The introduction of $S$. curvatum to French Polynesia may have occurred after 1998 when this species was introduced to France because trade between French Polynesia and this species' native range or its other exotic locations are practically non-existent. In 2007, S. curvatum was well established on Tahiti and in 2013 it was also found on Bora Bora of the Society Islands. Its rapid spread in this archipelago suggests a pre-adaptation or rapid adaptation to tropical conditions. Its progression in the Society Islands appears to be faster than that of other recently introduced Aculeata such as Anoplius toluca (Cameron, 1893) (Pompilidae) or Micromeriella marginella modesta (Smith, 1855) (Scoliidae) (RAMAgE et al., 2015a, b).

No nest of $S$. curvatum has yet been studied from French Polynesia but its spider preys are probably of the families Araneidae and Salticidae, as these are its preys in Europe and are also the preys of $S$. caementarium and $S$. laetum. It would be interesting to study its nests to see if it preys upon the Mogoplistidae (Orthoptera) species of French Polynesia, Ornebius novarae (Saussure, 1877).

Genus Chalybion Dahlbom, 1843

Chalybion bengalense (Dahlbom, 1845)

Pelopoeus bengalensis Dahlbom, 1845: 433.

Material examined. - French Polynesia : 1 \%, Moorea, Motu Temae, XI.2006, S. Charlat (CS);

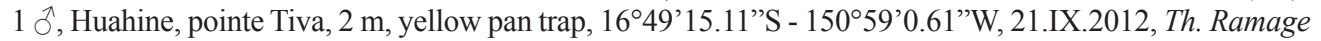
(CTR); New Caledonia : 1 ô, Muséum Paris, Nouvelle-Calédonie, coll. O. Sichel 1867, N. Caléd 63 (MNHN).

Diagnosis. - Medium-sized species (1.0-1.8 cm), metallic blue with infuscated wings. This species can't be confused with any other species of Sphecidae in French Polynesia due to its colour. It could be confused with another recently introduced metallic blue Aculeata species (Chrysis sp., RAMAGE \& KIMSEY, 2015) but the latter is stouter and does not have the long and tubular petiole between the mesosoma and the metasoma.

Distribution. - Oriental region, New Guinea, Australia (native range); Africa, Malagasy region, Pacific Islands, New Caledonia, French Polynesia (introduced). 
Biology. - Little is known about the biology of Chalybion bengalense, but it may ressemble the well known biology of C. californicum (Saussure, 1867). According to LANDES et al. (1987), the temporal variation of both prey species and numbers taken by $C$. californicum suggests that the wasps capture spiders not only according to size and habitat but also to relative and seasonal abundances. Mostly Araneidae and Theridiidae were chosen as preys in the USA, but spiders of the families Clubionidae, Mimetidae, Oxyopidae, Pisauridae, Salticidae, Tetragnathidae and Thomisidae were also preyed upon in smaller numbers.

C. californicum is an inquiline of other Sphecidae genera, with females not building their own nests but instead re-using nest cells of other mud dauber species (LANDES et al., 1987)

Comments. - Chalybion bengalense is new to New Caledonia and French Polynesia (Hensen, 1988; Jennings et al., 2013; Pulawski, 2013a).

No nests of $C$. bengalense have yet been studied from French Polynesia but the preyed spiders are probably of Araneidae and Theridiidae families, as in its native range.

\section{Identification Key to the Sphecidae of French Polynesia}

1. Metallic blue species

Chalybion bengalense (Dahlbom)

- Black and yellow species 2 (Genus Sceliphron)

2. Petiole curved (fig. 2) Sceliphron curvatum (Smith)

- Petiole straight (fig. 1) 3

3. Petiole black Sceliphron caementarium (Drury) - Petiole yellow Sceliphron laetum (Smith)

For all of these species the antennae of females have 12 segments, whereas males have 13 segments.

\section{CONCLUSION}

Although Sceliphron caementarium has been present in French Polynesia since at least the 1860s and is currently present in all five archipelagoes, the three newly introduced sphecid species Sceliphron laetum, S. curvatum and Chalybion bengalense are recent introductions and seem to be restricted to the Society Islands.

The newly recorded pompilid species Anoplius toluca (Cameron, 1893) (RAmAge et al., 2015a), the four sphecid species and seven species of Crabronidae (six Pison and one Trypoxylon) (Menke, 1979) all prey upon spiders. The spider fauna of French Polynesia, especially those of Araneidae, Salticidae, Thomisidae and Theridiidae families, seems to be heavily hunted by aculeate wasps, and it would be interesting to study the possible impact of these Hymenoptera on the diversity and distribution of spiders along altitudinal transects.

Acknowledgements. - This study has been partly funded by the Société d'Histoire naturelle Alcide-d'Orbigny, the program Terres et Mers Ultramarines, the Société des Amis du Muséum, the Société entomologique de France (Grant Germaine Cousin) and the program Symbiocode. All these structures and programs are thanked for their trust, without them the ongoing studies on the Hymenoptera of French Polynesia wouldn't exist. We also thank Dr Claire Villemant, Ms Agnièle Touret-Alby and Messrs Franck Muller and Quentin Rome (MNHN) for their welcome, help and advice. We deeply thank Jean-François Butaud, Michel Charleux, Marie-Hélène Burle, François Sanz, Claire Etienne, Céline Robert, Tetumu family, Laroche family, Masseron family, Romy Tavaearii, Terii Tetumu, Thierry Laroche, Jérôme Tarati, Jean-Yves Meyer, Jean-Claude Thibault, Ron Englund, Maruiti Terorotua, Noëlla Tutavae, the Association pour la protection de la vallée de Punaru'u, Caroline Blanvillain, Laurent Yan, Rainui Maraetefau and the SOP Manu for their contribution somehow in the study of the arthropods of French Polynesia. And finally many thanks to Dr Ben Hoffmann (CSIRO) for his review of our paper. 


\section{REFERENCES}

Berland L., 1945. - Remarques sur des Araignées capturées par des Hyménoptères prédateurs aux îles Marquises. Bulletin de la Société entomologique de France, 50 : 23-26.

Bitsch J. \& BARBIER Y., 2006. - Répartition de l'espèce invasive Sceliphron curvatum (F. Smith) en Europe et plus particulièrement en France (Hymenoptera, Sphecidae). Bulletin de la Société entomologique de France, 111 (2) : 227-237.

Cameron P., 1886. - On some Hymenoptera (chiefly undescribed) from Japan and the Pacific. Proceedings and Transactions of the Natural History Society of Glasgow, 1 : 263-276.

Ćetrović A., Mokrousov M. V., Plećas M., Bogusch P., Antić D., Đorović-Jovanović L., Krpo-Ćetković J. \& KarAmAn M., 2011. - Status of the potentially invasive asian species Sceliphron deforme in Europe, and an update on the distribution of S. curvatum (Hymenoptera: Sphecidae). Acta Entomologica Serbica, $16(1-2):$ 91-114.

CurTiss A., 1938. - A short zoology of Tahiti in the Society Islands. Brooklyn, New York : Guide Printing Company, XVI $+193 \mathrm{p}$.

Dанцвом A. G., 1845. - Hymenoptera Europaea praecipue borealia; formis typicis nonnullis Specierum Generumve Exoticorum aut Extraneorum propter nexum systematicus associatis; per Familias, Genera, Species et Varietates disposita atque descripta. Tomus: Sphex in sensu Linneano. Lund : Officina Lundbergiana, XLIV $+528 \mathrm{p}$.

Dierkens M. \& Charlat S., 2011. - Contribution à la connaissance des araignées des îles de la Société (Polynésie française). Revue Arachnologique, 17 (5) : 63-81.

DRURY D., 1773. - Illustrations of natural history. Wherein are exhibited upwards of two hundred and forty figures of exotic insects, according to their different genera; very few of which have hitherto been figured by any author, being engraved and coloured from nature, with the greatest accuracy, and under the author's own inspection, on fifty copper-plates. With a particular description of each insect: interspersed with remarks and reflections on the nature and properties of many of them. London: XXVII +130 p., $50 \mathrm{pl}$.

EATON E. R., 2014. - Bug Eric. All about insects, spiders, and other arthropods, focusing on North America north of Mexico. http://bugeric.blogspot.fr/2014/05/exclusive-important-wasp-bolo.html. Accessed the $22^{\text {nd }}$ of May 2014.

Elgar M. A. \& JebB M., 1999. - Nest Provisioning of the Mud-Dauber Wasp Sceliphron laetum (F. Smith): Body Mass and Taxa Specific Prey Selection. Behaviour, 136 (2) : 147-159.

Harris A. C., 1992. - Wasps of the genus Sceliphron (Hymenoptera: Sphecidae) intercepted in New Zealand. New Zealand Entomologist, 15 : 39-42.

Hensen R. V., 1987. - Revision of the subgenus Prosceliphron van der Vecht (Hymenoptera, Sphecidae). Tijdschrift Voor Entomologie, 129 : 217-261.

— 1988. - Revision of the nominate subgenus Chalybion Dahlbom (Hymenoptera, Sphecidae). Tijdschrift Voor Entomologie, 131 : 13-64.

Jennings J. T., KRogmann L. \& Burwell C., 2013. - Review of the hymenopteran fauna of New Caledonia with a checklist of species. Zootaxa, 3736 (1) : 1-53.

Landes D. A., Obin M. S., CAdy A. B. \& Hunt J. H., 1987. - Seasonal and latitudinal variation in spider prey of the mud dauber Chalybion californicum (Hymenoptera, Sphecidae). The Journal of Arachnology, $15: 249-256$.

Menke A. S., 1979. - 3 Sphecid Wasps Previously Unrecorded from Tahiti (Hymenoptera: Sphecidae). Proceedings of The Entomological Society of Washington, 81 : 303-303.

Platnick N. I., 2014. - The world spider catalog, version 14.5. American Museum of Natural History, online at http://research.amnh.org/entomology/spiders/catalog/index.html doi: 10.5531/db.iz.0001. Accessed the $3^{\text {rd }}$ of January 2014.

PULAWSKI W. J., 2013a. - http://research.calacademy.org/sites/research.calacademy.org/files/Departments/ ent/sphecidae/Genera_and_species_pdf/Chalybion.pdf. Accessed the $3^{\text {rd }}$ of January 2014. 2013b. - http://research.calacademy.org/sites/research.calacademy.org/files/Departments/ent/sphecidae/ Genera_and_species_pdf/Sceliphron.pdf. Accessed the $3^{\text {rd }}$ of January 2014.

Rahola P., 2005.- Observations sur la biologie de Sceliphron curvatum (Smith, 1870) dans le Gard (sur de la France) (Hymenoptera, Sphecidae). Bulletin de la Société entomologique de France, 110 (3) : 331-336. 
Rahola P., 2007. - Contribution à la connaissance de la répartition et de la biologie de l'espèce invasive Sceliphron curvatum (Smith, 1870) (Hymenoptera, Sphecidae) et description d'un comportement prédateur inédit. Bulletin de la Société d'Étude des Sciences naturelles de Nîmes et du Gard, 66 : 61-65.

Ramage Th., Grandgirard J. \& Durand F., 2015a. - The Aculeata of French Polynesia. I. First record of a Pompilid wasp (Hymenoptera, Pompilidae). Bulletin de la Société entomologique de France, 120 (1) : $15-18$.

Ramage Th., Grandgirard J. \& Schulten G. G. M., 2015b. - The Aculeata of French Polynesia. II. First record of Micromeriella marginella modesta (Smith) from Society Islands and Vanuatu (Hymenoptera, Scoliidae, Campsomerini). Bulletin de la Société entomologique de France, 120 (1) : 87-90

Ramage Th. \& Kimsey L. S., 2015. - The Aculeata of French Polynesia. IV. First record of Chrysis angolensis (Hymenoptera, Chrysididae). Bulletin de la Société entomologique de France, 120 (2) : 209-211.

Rau P., 1935. - The Spider Prey of the Mud Wasp, Sceliphron caementarium (Araneae, Hymen.: Sphegidae). Entomological News, 46 : 267-270.

RAU P. \& RaU N., 1916. - The biology of the mud-daubing wasps as revealed by the contents of their nests. The Journal of Animal Behavior, $6: 27-63$.

SAussure H. DE, 1867. - Reise der österreichschen Fregatte Novara um die Erde in den Jahren 1857 , 1858, 1859 unter den Befehlen des Commodore B. von Wüllerstorf-Urbair. Zoologischer Theil. Zweiter Band. Hymenoptera. Familien der Vespiden, Sphegiden, Pompiliden, Crabroniden und Heterogynen. Wien, 138 p., pl. I-IV.

SмIтн F., 1856. - Catalogue of hymenopterous insects in the collection of the British Museum. Part IV. Sphegidae, Larridae and Crabronidae. London : Taylor and Francis, p. 207-497.

1870. - Appendix, containing descriptions of some new species of Apidae and Vespidae collected by Mr. Horne (p. 186-194). In: Horne C., Notes on the habits of some hymenopterous insects from the North-west Provinces of India. Transactions of the Zoological Society of London, 7: 161-196, pl. 19-22.

VAN DeR Vecht J. \& VAN Breugel F. M. A., 1968. - Revision of the nominate subgenus Sceliphron Latreille (Hymenoptera, Sphecidae) (Studies on the Sceliphronini, Part I). Tijdschrift voor Entomologie, 111 : $185-255$.

Williams F. X., 1932. - The sphegoid wasps of the Marquesas Islands. Bulletin of the Bernice Pauahi Bishop Museum, 98 : 149-154. 